\title{
Molecular Events of Insulin Action Occur at Lipid Raft/Caveolae in Adipocytes
}

\author{
Sun Sik Bae ${ }^{1}$, Sung Ji Yun ${ }^{1}$, Eun Kyung Kim', Chi Dae Kim', Jang Hyun Choi ${ }^{2}$ \\ and Pann-Ghill Suh*.2 \\ ${ }^{1}$ Department of pharmacology and MRC for ischemic tissue regeneration, Pusan National University College of Medicine, Busan 602-739; \\ ${ }^{2}$ Department of Life Science, Division of Molecular and Life Science, Pohang University of Science and Technology, Pohang 790-784, Republic of \\ Korea
}

Received November 15, 2006 / Accepted December 17, 2006

\begin{abstract}
Insulin stimulates the fusion of intracellular vesicles containing glucose transporter 4 (GLUT4) with plasma membrane in adipocytes and muscle cells. Here we show that adipocyte differentiation results in enhanced insulin sensitivity of glucose uptake. On the other hand, glucose uptake in response to platelet-derived growth factor (PDGF) stimulation was markedly reduced by adipocyte differentiation. Expression level of insulin receptor and caveolin-1 was dramatically increased during adipocyte differentiation. Adipocyte differentiation caused slightly enhanced activation of acutely transforming retrovirus AKT8 in rodent T cell lymphoma (Akt) by insulin stimulation. However, activation of Akt by PDGF stimulation was largely reduced. Activation of ERK was not detected in both fibroblasts and adipocytes after stimulation with insulin. PDGF-dependent activation of ERK was reduced by adipocyte differentiation. Insulin-dependent glucose uptake was abrogated by LY294002, a phosphatidylinositol 3-kinase (PI3K) inhibitor, in both fibroblasts and adipocytes. Also disassembly of caveolae structure by methyl- $\beta$-cyclodextrin caused impairment of Akt activation and glucose uptake. Finally, insulin receptor, Akt, SH2-domain-containing inositol 5-phosphatase 2 (SHIP2), and regulatory subunit of PI3K are localized at lipid raft domain and the translocation was facilitated upon insulin stimulation. Given these results, we suggest that lipid raft provide proper site for insulin action for glucose uptake.
\end{abstract}

Key words - glucose uptake, GLUT4, Akt, Insulin, lipid raft

\section{Introduction}

Adipocytes are not only storage cells but are also specialized cells under the influence of various hormones, cytokines, and nutrients, and exert pleiotropic functions. The major function of adipocytes is to control full body fuel homeostasis[9]. One of the metabolic processes that are acquired during adipocyte differentiation is a highly insulin-responsive glucose-transport system[24]. For example, stimulation of insulin redistributes intracellular vesicle containing the glucose transporter GLUT4 to the cell surface membrane by process called translocation. These plasma membrane-localized transporters subsequently facilitate influx of glucose into the cell. Impairment in the insulin receptor signal linking GLUT4 vesicle has been described and is speculated to be a molecular and physiological basis for insulin-resistant status in obesity and type 2 diabetes.

Binding of insulin to its cognate receptor evokes ty-

\section{*Corresponding author}

Tel : +82-54-279-2293, Fax : +82-54-279-0645

E-mail : pgs@postech.ac.kr rosine phosphorylation of insulin receptor substrate (IRS) protein, which provides binding site for p85 subunit of phosphatidylinositol 3-kinase (PI3K)[6]. Multiple studies using various pharmacological inhibitors, dominant negative and/or constitutive active version of constructs have demonstrated pivotal roles of PI3K in insulin-stimulated GLUT4 translocation[7,10,14]. Increased level of phosphatidylinositol 3, 4, 5-trisphosphate ( $\mathrm{PIP}_{3}$ ) by PI3K leads to the activation of protein kinase cascade such as 3-phosphoinositide-dependent kinase-1 (PDK-1), protein kinase B/Akt (PKB), and atypical protein kinase C (PKC). Especially, Akt is primarily activated by PDK-1 upon insulin stimulation [1] and full activation is achieved by phosphorylation at $\mathrm{Ser}^{473}$ residue by Rictor-mTOR complex, which sense nutritional status[25]. Although it is now clear that above kinases are involved in insulin-mediated glucose uptake, exact interrelationship among those kinases requires further investigation.

Despite the essential nature of PI3K, substantial information suggests that insulin signaling requires additional mechanisms for GLUT4 translocation[12,13]. For ex- 
ample, insulin signaling gets assists from certain region of plasma membrane of distinct lipid and protein composition, referred to as lipid raft/caveolae domain[4,29]. Caveolae represents subset of lipid rafts that are formed from polymerization of caveolins, hairpin-like palmitoylated integral membrane proteins that strongly binds cholesterol[4], and is indicated to be important for insulin receptor signaling[11]. Also, insulin receptors are found to be located in caveolae of adipocyte plasma membrane[16], and many signaling molecules involved in insulin receptor signal cascade are also found to be enriched in lipid $\mathrm{raft} /$ caveolae[31]. In addition to signaling proteins, it has been reported that phosphoinositide turnover occurs at lipid raft domain[23], GLUT4 itself is localized at lipid raft/caveolae[19]. Other reports have demonstrated that $\mathrm{Cbl}$ and $\mathrm{Cbl}$-associated protein (CAP) are also important for insulin-induced glucose uptake[3,8]. Therefore, studies on the assessment of PI3K involvement in a concert with lipid raft domain have to be undertaken to dissect insulin-induced GLUT4 translocation and glucose uptake.

Adipocyte differentiation changes cells to highly insulin-sensitive status. Adipocyte differentiation requires an interplay between the peroxisome proliferator-activated receptor-g (PPAR-g) and two other groups of transcriptional factors: the CCAATT/enhancer binding proteins (C/EBP) and ADD-1/ SREBP-1[33]. Although all of these transcriptional factors can independently induce adipocyte differentiation in vitro, they act synergistically in vivo. Sequential expression of adipogenic transcriptional factors during adipocyte differentiation induces the expression of another set of genes that provide fat cells with highly insulin responsive context. However, few of genes have identified as insulin sensitizer so far. In this study, we provide evidences that expression of insulin signaling molecules and structural protein of lipid raft are increased during adipocyte differentiation and that integration of insulin signaling molecules at the lipid raft is essential for GLUT4 translocation and glucose uptake.

\section{Materials and Methods}

\section{Materials}

Insulin and platelet-derived growth factor (PDGF) were obtained from Sigma-Aldrich. 2-[1,2- $\left.{ }^{3} \mathrm{H}\right]$ Deoxy-D-glucose (30Ci/ mmole) was purchased from Amersham Pharmacia. Methyl- $\beta$-cyclodextrin was obtained from Sigma-Aldrich.
LY294002 and PD98059 were purchased from Calbiochem. Anti-Akt, anti-phospho-Akt $\left(\mathrm{Ser}^{473}\right)$ antibodies were obtained from Cell Signaling Technology Inc. Anti-insulin receptor (IR), anti-p85 PI3K, anti-phospho-ERK, anti-SHIP2, anti-actin antibody were purchased from Upstate Biotechnology Inc. Anti-flotillin-1 and anti-caveolin-1 antibody were obtained from BD Transduction Laboratory. All other high quality reagents were purchased from Sigma-Aldrich unless indicated elsewhere.

\section{Cell culture and differentiation of 3T3-L1}

3T3-L1 preadipocytes were maintained in Dulbecco's modified Eagle's medium (DMEM) containing $10 \%$ bovine calf serum at $37{ }^{\circ} \mathrm{C}$ in $5 \% \mathrm{CO}_{2}$. To reserve differentiation potency, cells were maintained at less than $50 \%$ confluency. Adipocyte differentiation was conducted as described previously[2]. Briefly, 3T3-L1 preadipocytes were seeded at high density and keep cultured for another two days to reach confluent. After 2 days post-confluent stage, medium was switched to differentiation cocktail containing $10 \%$ fetal bovine serum (FBS), $2 \mu \mathrm{g} / \mathrm{ml}$ of insulin, $0.4 \mu \mathrm{g} /$ $\mathrm{ml}$ of dexamethason, and $0.5 \mathrm{mM}$ of isobutyl-methyl xanthine in DMEM. Two days later, medium was changed with fresh differentiation cocktail and incubated for another 2 days. Four days after induction of differentiation, medium was switched to normal medium for another 4 days. Cells at 8-10 days post-differentiation were used for the experiments.

\section{2-deoxyglucose uptake}

2-deoxyglucose uptake of preadipocytes and adipocytes were done as described elsewhere with slight modification[15]. Briefly, cells grown in 12-well plates were washed two times with serum-free DMEM and starved overnight. The cells were washed three times with KRP buffer $\left(136 \mathrm{mM} \mathrm{NaCl}, 4.7 \mathrm{mM} \mathrm{KCl}, 0.9 \mathrm{mM} \mathrm{CaCl}_{2}, 0,9 \mathrm{mM}\right.$ $\mathrm{MgSO}_{4}, 10 \mathrm{mM}$ sodium phosphate buffer, $\mathrm{pH}$ 7.4) containing $0.2 \%$ bovine serum albumin (BSA), and incubated for $30 \mathrm{~min}$ in $0.42 \mathrm{ml}$ KRP buffer containing $0.2 \% \mathrm{BSA}$. Thirty microliter of insulin solution (100 $\mathrm{nM}$ in KRP buffer containing $0.2 \% \mathrm{BSA}$ ) was added for $20 \mathrm{~min}$. With $5 \mathrm{~min}$ remaining, $50 \mathrm{ml}$ of 10X START Solution (1 mM 2-deoxyglucose, $5 \mu \mathrm{Ci} / \mathrm{ml}$ of $\left[{ }^{3} \mathrm{H}\right]$-2-deoxyglucose) was added to the $0.45 \mathrm{ml}$ of insulin-stimulated KRP/BSA solution. To subtract non-specific binding, $10 \mu \mathrm{M}$ of cytochalasin B was added at time of insulin stimulation. The reaction was ter- 
minated by aspirating the medium and washing the plates three times with cold PBS. The cells were solubilized with $0.5 \mathrm{ml}$ of $0.05 \%$ sodium dodecyl sulfate (SDS) in PBS and the radioactivity determined in a $0.3 \mathrm{ml}$ aliquot by liquid scintillation counter.

\section{Sucrose density gradient fractionation of lipid raft}

Isolation of lipid raft by detergent-free sucrose density gradient fractionation was performed as described previously[32]. In brief, cells were suspended in $2 \mathrm{ml}$ of 500 $\mathrm{mM}$ sodium carbonate buffer, $\mathrm{pH} 11$. Sodium vanadate (1 $\mathrm{mM}$ ) was present at all steps. The cells suspensions were homogenized with 10 strokes of Dounce homogenizer, three $10 \mathrm{sec}$ bursts of a Polytron tissue grinder, and three bursts of a sonicator. The homogenate was then adjusted to $45 \%$ sucrose by addition of $80 \%$ sucrose prepared in MES buffer (150 mM NaCl, $1 \mathrm{mM}$ EGTA, $1 \mathrm{mM} \mathrm{Na}_{3} \mathrm{VO}_{4}$, $25 \mathrm{mM}$ MES, $\mathrm{pH}$ 6.5) and transferred to ultracentrifugation tubes. A 5-35\% discontinuous sucrose gradient was formed on top of the samples. The samples were centrifuged at $39,000 \mathrm{rpm}$ for $6 \mathrm{hrs}$ in a SW41 rotor. Fractions were collected from the top of the tubes in $1 \mathrm{ml}$ amount.

\section{Western blot analysis}

Cells were lysed with lysis buffer containing $20 \mathrm{mM}$ Tris- $\mathrm{HCl}$ pH 7.3, $1 \mathrm{mM}$ EGTA/EDTA, $10 \mathrm{mM} \mathrm{NaF}, 1 \%$ Triton $\mathrm{X}-100,1 \mathrm{mM} \mathrm{Na}_{3} \mathrm{VO}_{4}$, and $10 \%$ glycerol. Forty $\mathrm{mg}$ of cell lysates were submitted to SDS-polyacrylamide gel electrophoresis on 7\%-18\% gradient polyacrylamide gel under reduced conditions. Following transfer to nitrocellulose membranes, the membranes were subjected to immunoblotting using indicated antibody in figures and HRP-conjugated secondary antibodies. Western blots were developed using enhanced chemiluminescence (Amersham Pharmacia Biotech).

\section{Results and Discussion}

\section{Adipocyte differentiation enhanced insulin-induced glucose uptake}

Insulin is believed to be unique among growth factors and hormones in its ability to control metabolic functions such as the stimulation of glucose uptake, lipolysis, and protein synthesis in metabolic organs and tissues. However, many reports have suggested that other hor- mones such as PDGF and insulin-like growth factor-1 (IGF-1) also can induce certain amount of glucose uptake in isolated metabolic cells $[27,28,37,38]$. Nonetheless, the signaling specificity remains to be elucidated, particularly, in view of some other growth factors that share similar signaling events

Metabolic function of insulin is enhanced during differentiation. As shown in Fig. 1, adipocyte differentiation strongly augmented insulin-dependent glucose uptake. On the other hand, PDGF-dependent glucose uptake was markedly reduced by adipocyte differentiation. Adipocyte differentiation also abrogates IGF-1-induced glucose uptake[27] though IGF-1 seems to be critical inducer of differentiation[30]. Reduction of PDGF-dependent glucose uptake is resulted from decreased expression of PDGF receptor gene[26]. As shown in Fig. 1, adipocytes still respond to PDGF stimulation. This result might come from incomplete differentiation of the cells and/or PDGF receptor signaling also contributes GLUT4 translocation and glucose uptake. Eileen and her colleagues have demonstrated that PDGF receptor signaling in adipocytes elicits GLUT4 translocation and glucose uptake in the absence of insulin receptor substrate (IRS) activation[37]. Therefore, enhanced insulin or decreased PDGF response in adipocyte seems to be caused by dynamic changes of receptor expression, and common signaling pathway in between insulin receptor and PDGF receptor is important for glucose uptake.

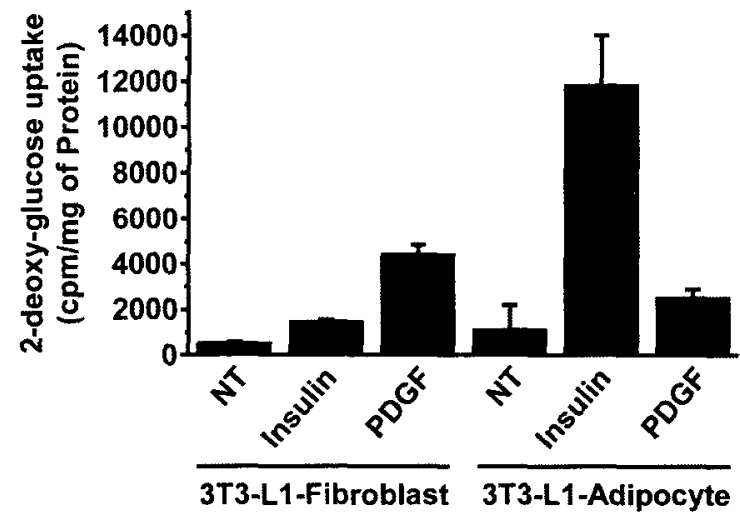

Fig. 1. Insulin- and PDGF-induced glucose uptake in fibroblasts and adipocytes. Both cells were pretreated with either insulin (100 nM) or PDGF $(50 \mathrm{ng} / \mathrm{ml})$ for 15 $\mathrm{min}$, and glucose uptake during last $5 \mathrm{~min}$ was measured as described in "Materials and Methods" Data are mean \pm SEM of three duplicated experiments. 
Insulin-induced glucose uptake is mediated by PI3K activation

Both insulin and PDGF elicit activation of PI3K and ERK pathways. It is now well accepted that $p 42 / p 44$ mitogen activated protein kinase (MAPK) is not involved in insulin-induced glucose uptake (Fig. 2)[21]. As shown in Fig. 2, pretreatment of both fibroblasts and adipocytes with PD98059 did not affect PDGF- or insulin-induced glucose uptake. These results indicate that activation of MAPK is not involved in GLUT4 translocation and glucose uptake. However, pretreatment of both fibroblasts and adipocytes with LY294002 completely blocked PDGF- or insulin- induced glucose uptake. The importance of PI3K signaling in hormone-induced glucose uptake is further verified via mutant PDGF receptor expression in adipocytes[37]. For example, mutation at binding sites for $\mathrm{p} 85$ regulatory subunit of PI3K impairs PDGF-induced GLUT4 translocation and glucose uptake. Our results also indicate that PI3K pathway is important for glucose uptake in both fibroblasts and adipocytes (Fig. 2). However, the question about how adipocyte acquires more sensitive cellular context for insulin stimulation remains to be elucidated though increased insulin receptor expression seems to be causative for enhanced glucose uptake in adipocyte.

Insulin signaling molecules are up regulated during adipocyte differentiation

The answer for increased insulin response might be re-

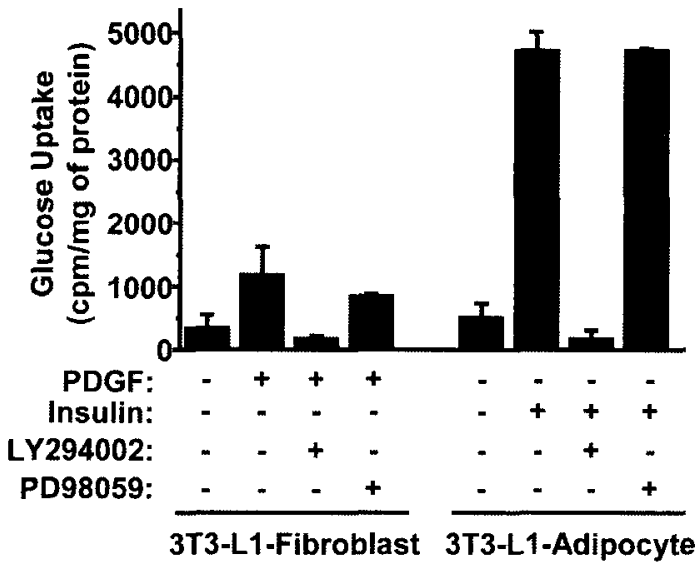

Fig. 2. Effect of PI3K and MAPK inhibitors on insulin- or PDGF-induced glucose uptake. Both fibroblasts and adipocytes were pretreated with either LY294002 (20 $\mu \mathrm{M})$ or PD98059 $(1 \mu \mathrm{M})$ for $20 \mathrm{~min}$. Glucose uptake was measured as described in "Materials and Methods" Data are the mean \pm SEM of three duplicated experiments. lated with gene expression of insulin signaling molecules. Actually, adipocyte differentiation enhanced gene expression of insulin receptor about 10 -fold (Fig. 3). Also it has been reported that expression of insulin responsive Akt2 but not Akt1 is enhanced during adipocyte differentiation[34]. Expression of glucose transporter GLUT4 is also induced during adipocyte differentiation (unpublished data). However, expression of PDGF receptor is reduced during adipocyte differentiation[35]. Therefore, differentiation to metabolic fat cells augments insulin responsive glucose uptake and abolishes glucose uptake in response to PDGF stimulation. Also, changes in cellular context by differentiation makes insulin as unique metabolic regulator in organism level.

Beside insulin signaling molecules, expression of caveolin-1, a structural protein of lipid raft, is induced after adipocyte differentiation (Fig. 3). Lipid raft/caveolae is thought to be important for insulin signaling[4,11]. It has been known that insulin activates two major signaling pathways such as PI3K-Akt and ERK. Recently, we have reported that one of the insulin signaling molecules, serine/threonine protein kinase Akt2, is important for insulin-induced GLUT4 translocation and glucose uptake[2]. As shown in Fig. 3, adipocyte differentiation resulted in the enhancement of insulin-dependent activation of Akt or reduction of PDGF-dependent activation of Akt. However,

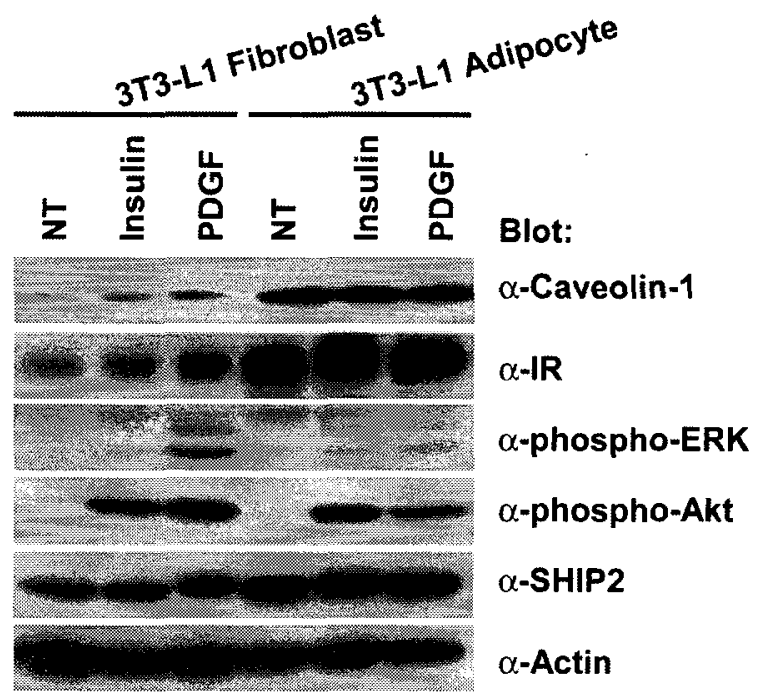

Fig. 3. Expression of insulin signaling molecules during adipocyte differentiation. Both fibroblasts and adipocytes were stimulated with either insulin $(100 \mathrm{nM})$ or PDGF $(50 \mathrm{ng} / \mathrm{ml})$ for $10 \mathrm{~min}$ and expression of indicated proteins were detected by western blotting as described in "Materials and Methods" 
stimulation of adipocytes with insulin did not activate ERK (Fig. 3). Moreover, pharmacological ERK inhibitor such as PD98059 did not affect insulin-induced glucose uptake (Fig. 2). Given these results, we suggest here that adipocyte differentiation confer enhancement of insulin signaling such as PI3K-Akt, and that ERK signaling pathway is not involved in insulin-induced glucose uptake. The interrelationship in between PI3K-Akt signaling pathway and lipid raft/caveolae should be addressed.

\section{Disruption of lipid raft/caveolae abolished insulin-} induced glucose uptake

As shown in Fig. 3, expression of caveolin-1 is dramatically increased during adipocyte differentiation, and glucose uptake in response to insulin stimulation is also augmented by adiocyte differentiation (Fig. 1 and Fig. 2). Depletion of cholesterol by methyl- $\beta$-cyclodextrin (MCD) destroys lipid raft/caveolae structure[22], and abolishes insulin-induced glucose uptake in adipocytes but not PDGF-induced glucose uptake in fibroblasts (Fig. 4). This result correlates with many other reports suggesting that insulin signaling molecules are integrated into lipid raft/caveolae structure[11,16,18,19]. Since expression of

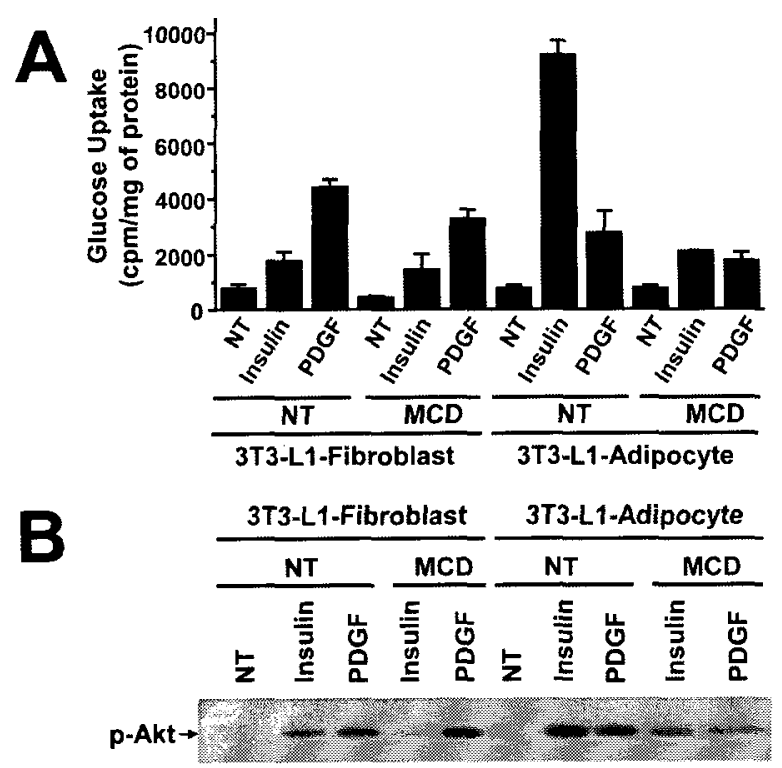

Fig. 4. Effect of cholesterol depletion on the glucose uptake and insulin-induced phosphorylation of Akt. $0.2 \mathrm{mM}$ cholesterol complex with MCD was applied to both fibroblasts and adipocytes, and subsequently glucose uptake was measured after simulation with either insulin $(100 \mathrm{nM})$ or PDGF $(50 \mathrm{ng} / \mathrm{ml})(\mathrm{A})$, or activation of Akt was detected by western blotting (B). Data are mean $\pm S E M$ of three duplicated experiments. caveolin-1 is increased during adipocyte differentiation, it is possible that MCD will affect glucose uptake in adipocytes rather than fibroblasts that express relatively low level of caveolin-1 and lipid raft/caveolae. Destroy of lipid raft/caveolae structure by MCD also caused defect of Akt activation by both insulin and PDGF (Fig. 4). Involvement of lipid raft/caveolae in insulin-induced glucose uptake and Akt activation was also reported in other cells types such as $\mathrm{H} 9 \mathrm{c} 2$ cardiomyoblasts[17]. Therefore, involvement of lipid raft/caveolae in Akt activation and glucose uptake is apparent. However, it is also possible that lipid raft/caveolae provide docking site for the fusion of GLUT4 vesicle with plasma membrane regardless activation of PI3K-Akt signaling pathway[5,19].

Localization of insulin signaling molecules to lipid raft

Though we have shown that destroy of caveolae abolishes insulin-induced glucose uptake and Akt activation, it is still necessary to provide evidence that Akt is localized and activated at lipid raft/caveolae microdomain. As shown in Fig. 5, we have fractionated samples by using sucrose-density gradient and isolation of lipid raft/caveolae is verified by wetern blotting with marker proteins such as caveolin-1 and flotillin-1. Significant amount of insulin re-

Fraction NO: 234567891011

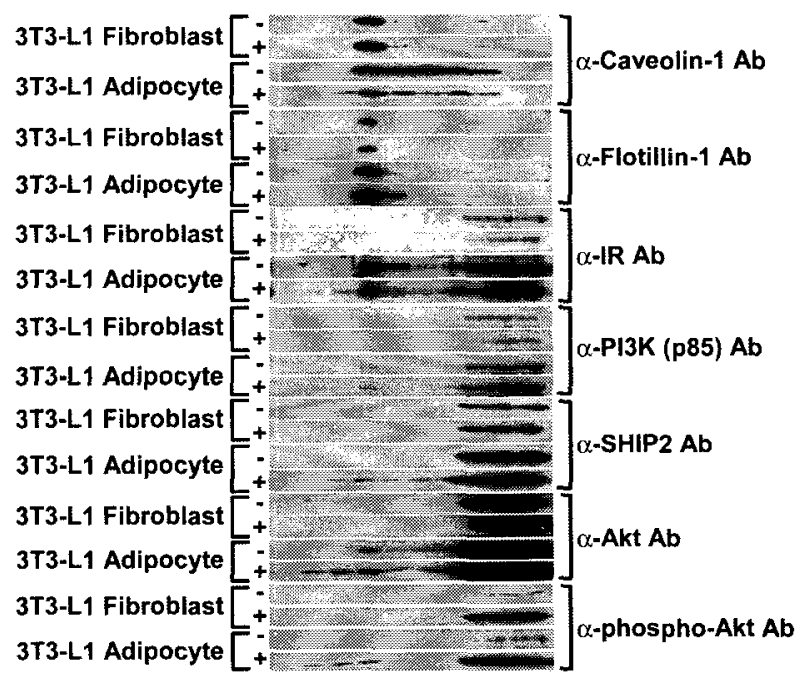

Fig. 5. Localization of insulin signaling molecules at lipid raft/caveolae microdomain. Bothe fibroblasts and adipocytes were stimulated with either PDGF $(50 \mathrm{ng} / \mathrm{ml})$ or insulin $(100 \mathrm{nM})$ for $10 \mathrm{~min}$, respectively. Cells were fractionated on sucrose-density gradient as described in "Materials and Methods" and each fraction was subjected western blotting with indicated antibodies. 
ceptor was localized at lipid raft/caveolae microdomain (Fig. 5)[16]. Interestingly, the regulatory subunit of p85 PI3K was also found in lipid raft/caveolae microdomain. These results suggest that activation of insulin receptor and PI3K might occur at lipid raft/caveolae, and subsequent production of phosphatidylinositol 3,4,5-trisphosphate $\left(\mathrm{PIP}_{3}\right)$ and activation of downstream target molecules such as PDK-1 and Akt occurs at the same site. The catalytic product of $\mathrm{PI} 3 \mathrm{~K}, \mathrm{PIP}_{3}$, is converted to $\mathrm{PIP}_{2}$ by dephosphorylaton of phosphate at D5 position of inositol ring. This reaction is carried out by lipid phosphatase SHIP2, which is 5'-phosphatase containing SH2 domain[20]. SHIP2 also modulates insulin signaling and controls its metabolic functions[36]. Our results also showed that SHIP2 was also localized at lipid raft/caveolae microdomain in insulin-dependent manner (Fig. 5). Given these results, we provide evidences that negative and positive PI3K signaling molecules are co-localized at lipid raft/caveolae microdomain. Next, we have verified activation of Akt, which is a key regulator of GLUT4 translocation and glucose uptake, at lipid raft/caveolae microdomain. Stimulation of adipocytes with insulin resulted in translocation of Akt from cytosol to lipid raft/caveolae microdomain. Also significant amount of phosphorylated Akt (active form) was detected at lipid raft/caveolae microdomain (Fig. 5). These results indicate that lipid raft/caveolae is essential membrane site for both stimulatory and inhibitory insulin signaling.

Our results provide three major evidences that lipid $\mathrm{raft} /$ caveolae is crucial membrane structure for proper insulin signaling. First, adipocytes are more sensitive than fibroblasts in response to insulin-induced glucose uptake, and expression of caveolin- 1 is increased during adipocyte differentiation. Though the expression of insulin receptor itself is induced by adipocyte differentiation, MCD-induced lipid raft/caveolae disruption studies showed that lipid raft/caveolae microdomain plays pivotal roles in insulin signaling. Second, PI3K-Akt signaling molecules play crucial roles in GLUT4 translocation and glucose uptake rather than other ERK signaling pathways. Disruption of lipid raft/caveolae also abolished insulin-induced activation of PI3K-Akt pathway. Finally, insulin signaling molecules such as insulin recptor, p85 PI3K, Akt, and SHIP2 are localized at lipid raft/caveolae. Therefore, we suggest here that lipid raft/caveolae may provide essential site for insulin signaling molecules to induce GLUT4 translocation and glucose uptake.

\section{Acknowledgements}

This work was supported for two years by Pusan National University Research Grant to S.S.B.

\section{References}

1. Alessi, D. R., S. R. James, C. P. Downes, A. B. Holmes, P. R. Gaffney, C. B. Reese, and P. Cohen. 1997. Characterization of a 3-phosphoinositide-dependent protein kinase which phosphorylates and activates protein kinase Ba. Curr. Biol. 7, 261-269.

2. Bae, S. S., H. Cho, J. Mu, and M. J. Birnbaum. 2003. Isoform-specific regulation of insulin-dependent glucose uptake by Akt/protein kinase B. I. Biol. Chem. 27, 49530-49536.

3. Baumann, C. A., V. Ribon, M. Kanzaki, D. C. Thurmond, S. Mora, S. Shigematsu, P. E. Bickel, J. E. Pessin, and A. R. Saltiel. 2000. CAP defines a second signalling pathway required for insulin-stimulated glucose transport. Nature 407, 202-207.

4. Bickel, P. E. 2002. Lipid rafts and insulin signaling. Am. J. Physiol. Endocrinol. Metab. 282, E1-E10.

5. Chamberlain, L. H., and G. W. Gould. 2002. The vesicleand target-SNARE proteins that mediate Glut4 vesicle fusion are localized in detergent-insoluble lipid rafts present on distinct intracellular membranes. J. Biol. Chem. 277, 49750-49754

6. Cheatham, B., and C. R. Kahn. 1995. Insulin action and the insulin signaling network. Endocr. Rev. 16, 117-142.

7. Cheatham, B., C. J. Vlahos, L. Cheatham, L. Wang, J. Blenis, and C. R. Kahn. 1994. Phosphatidylinositol 3-kinase activation is required for insulin stimulation of pp70 $\mathrm{S6}$ kinase, DNA synthesis, and glucose transporter translocation. Mol. Cell. Biol. 14, 4902-4911.

8. Chiang, S. H., C. A. Baumann, M. Kanzaki, D. C. Thurmond, R. T. Watson, C. L. Neudauer, I. G. Macara, J. E. Pessin, and A. R. Saltiel. 2001. Insulin-stimulated GLUT4 translocation requires the CAP-dependent activation of TC10. Nature 410, 944-948.

9. Cinti, S. 2005. The adipose organ. Prostaglandins Leukot. Essent. Fatty Acids 73, 9-15.

10. Clarke, J. F., P. W. Young, K. Yonezawa, M. Kasuga, and G. D. Holman. 1994. Inhibition of the translocation of GLUT1 and GLUT4 in 3T3-L1 cells by the phosphatidylinositol 3-kinase inhibitor, wortmannin. Biochem. J. 300 (Pt 3), 631-635.

11. Czech, M. P. 2000. Lipid rafts and insulin action. Nature 407, 147-148.

12. Czech, M. P., and S. Corvera. 1999. Signaling mechanisms that regulate glucose transport. I. Biol. Chem. 274, 1865-1868. 
13. Elmendorf, J. S., and J. E. Pessin. 1999. Insulin signaling regulating the trafficking and plasma membrane fusion of GLUT4-containing intraceliular vesicles. Exp. Cell Res. 253, 55-62.

14. Frevert, E. U., and B. B. Kahn. 1997. Differential effects of constitutively active phosphatidylinositol 3-kinase on glucose transport, glycogen synthase activity, and DNA synthesis in 3T3-L1 adipocytes. Mol. Cell. Biol. 17, 190-198.

15. Garcia de Herreros, A., and M. J. Birnbaum. 1989. The acquisition of increased insulin-responsive hexose transport in 3T3-L1 adipocytes correlates with expression of a novel transporter gene. J. Biol. Chem. 264, 19994-19999.

16. Gustavsson, J., S. Parpal, M. Karlsson, C. Ramsing, H. Thorn, M. Borg, M. Lindroth, K. H. Peterson, K. E. Magnusson, and P. Stralfors. 1999. Localization of the insulin receptor in caveolae of adipocyte plasma membrane. FASEB J. 13, 1961-1971.

17. Ha, H., and Y. Pak. 2005. Modulation of the caveolin-3 and Akt status in caveolae by insulin resistance in $\mathrm{H} 9 \mathrm{c} 2$ cardiomyoblasts. Exp. Mol. Med. 37, 169-178.

18. Hong, S., H. Huo, J. Xu, and K. Liao. 2004. Insulin-like growth factor-1 receptor signaling in 3T3-L1 adipocyte differentiation requires lipid rafts but not caveolae. Cell Death Differ. 11, 714-723.

19. Karlsson, M., H. Thorn, S. Parpal, P. Stralfors, and J. Gustavsson. 2002. Insulin induces translocation of glucose transporter GLUT4 to plasma membrane caveolae in adipocytes. FASEB J. 16, 249-251.

20. Krystal, G., J. E. Damen, C. D. Helgason, M. Huber, M. R. Hughes, J. Kalesnikoff, V. Lam, P. Rosten, M. D. Ware, S. Yew, and R. K. Humphries. 1999. SHIPs ahoy. Int. J. Biochem. Cell Biol. 31, 1007-1010.

21. Lazar, D. F., R. J. Wiese, M. J. Brady, C. C. Mastick, S. B. Waters, K. Yamauchi, J. E. Pessin, P. Cuatrecasas, and A. R. Saltiel. 1995. Mitogen-activated protein kinase kinase inhibition does not block the stimulation of glucose utilization by insulin. J. Biol. Chem. 270, 20801-20807.

22. Parpal, S., M. Karlsson, H. Thorn, and P. Stralfors. 2001. Cholesterol depletion disrupts caveolae and insulin receptor signaling for metabolic control via insulin receptor substrate-1, but not for mitogen-activated protein kinase control. J. Biol. Chem. 276, 9670-9678.

23. Pike, L. J., and L. Casey. 1996. Localization and turnover of phosphatidylinositol 4,5-bisphosphate in caveolin- enriched membrane domains. J. Biol. Chem. 271, 26453-26456.

24. Rubin, C. S., E. Lai, and O. M. Rosen. 1977. Acquisition of increased hormone sensitivity during in vitro adipocyte development. J. Biol. Chem. 252, 3554-3557.

25. Sarbassov, D. D., D. A. Guertin, S. M. Ali, and D. M. Sabatini. 2005. Phosphorylation and regulation of Akt/ PKB by the rictor-mTOR complex. Science 307, 1098-1101.

26. Shigematsu, S., S. L. Miller, and J. E. Pessin. 2001. Differentiated 3T3L1 adipocytes are composed of heterogenous cell populations with distinct receptor tyrosine kinase signaling properties. J. Biol. Chem. 276, 15292-15297.
27. Shimizu, M., F. Torti, and R. A. Roth. 1986. Characterization of the insulin and insulin-like growth factor receptors and responsitivity of a fibroblast/adipocyte cell line before and after differentiation. Biochem. Biophys. Res. Commun. 137, 552-558.

28. Siddals, K. W., M. Westwood, J. M. Gibson, and A. White. 2002. IGF-binding protein-1 inhibits IGF effects on adipocyte function: implications for insulin-like actions at the adipocyte. J. Endocrinol. 174, 289-297.

29. Simons, K., and D. Toomre. 2000. Lipid rafts and signal transduction. Nat. Rev. Mol. Cell. Biol. 1, 31-39.

30. Smith, P. J., L. S. Wise, R. Berkowitz, C. Wan, and C. S. Rubin. 1988. Insulin-like growth factor-I is an essential regulator of the differentiation of 3T3-L1 adipocytes. I. Biol. Chem. 263, 9402-9408.

31. Smith, R. M., S. Harada, J. A. Smith, S. Zhang, and L. Jarett. 1998. Insulin-induced protein tyrosine phosphorylation cascade and signalling molecules are localized in a caveolin-enriched cell membrane domain. Cell Signal. 10, 355-362.

32. Song, K. S., S. Li, T. Okamoto, L. A. Quilliam, M. Sargiacomo, and M. P. Lisanti. 1996. Co-purification and direct interaction of Ras with caveolin, an integral membrane protein of caveolae microdomains. Detergent-free purification of caveolae microdomains. J. Biol. Chem. 271, 9690-9697.

33. Spiegelman, B. M., and J. S. Flier. 1996. Adipogenesis and obesity: rounding out the big picture. Cell 87, 377-389.

34. Summers, S. A., E. L. Whiteman, H. Cho, L. Lipfert, and M. J. Birnbaum. 1999. Differentiation-dependent suppression of platelet-derived growth factor signaling in cultured adipocytes. J. Biol. Chem. 274, 23858-23867.

35. Vaziri, C., and D. V. Faller. 1996. Down-regulation of platelet-derived growth factor receptor expression during terminal differentiation of 3T3-L1 pre-adipocyte fibroblasts. J. Biol. Chem. 271, 13642-13648.

36. Wada, T., T. Sasaoka, M. Funaki, H. Hori, S. Murakami, M. Ishiki, T. Haruta, T. Asano, W. Ogawa, H. Ishihara, and M. Kobayashi. 2001. Overexpression of SH2- containing inositol phosphatase 2 results in negative regulation of insulin-induced metabolic actions in 3T3-L1 adipocytes via its 5 -phosphatase catalytic activity. Mol. Cell. Biol. 21, 1633-1646.

37. Whiteman, E. L., J. J. Chen, and M. J. Birmbaum. 2003. Platelet-derived growth factor (PDGF) stimulates glucose transport in 3T3-L1 adipocytes overexpressing PDGF receptor by a pathway independent of insulin receptor substrates. Endocrinology 144, 3811-3820.

38. Yuasa, T., R. Kakuhata, K. Kishi, T. Obata, Y. Shinohara, Y. Bando, K. Izumi, F. Kajiura, M. Matsumoto, and Y. Ebina. 2004. Platelet-derived growth factor stimulates glucose transport in skeletal muscles of transgenic mice specifically expressing platelet-derived growth factor receptor in the muscle, but it does not affect blood glucose levels. Diabetes 53, 2776-2786. 


\section{초록 : 지방세포의 Lipid Raft/Caveolae에서 인슐린의 분자적 작용기전}

배순식 ${ }^{1}$ 윤성지 ${ }^{1}$ - 김은경 ${ }^{1}$ - 김치대 ${ }^{1} \cdot$ 최장현 ${ }^{2} \cdot$ 서판길 $^{2 *}$

('부산대학교, ${ }^{2}$ 포항공과대학교)

인슐린은 지방세포 또는 근육세포에서 포도당 홉수 조절 통로단백질이 함유되어 있는 소포제를 세포막으로의 이동을 촉진시킨다. 우리는 여기서 지방세포로의 분화는 인슐린에 의한 포도당 홉수에 대한 반응이 증가됨을 보 였다. 반면에 지방세포로의 분화는 PDGF에 의한 포도당 흡수 반응이 감소됨을 보였다. 인슐런 수용체나 caveolae는 지방세포로의 분화과정 동안 발현이 증가된다. 또한 지방세포로의 분화는 인슐린에 의한 Akt의 활성을 증가시켰다. 하지만 PDGF에 의한 Akt의 활성은 크게 감소하였다. 하지만 인슐린은 지방세포 또는 섬유아 전구세 포에서 ERK의 활성을 유도하지 않았다. PDGF에 의한 ERK 활성 또한 지방세포로의 분화과정에 따라 감소하였 다. P13K의 저해제인 LY294002는 지방세포 뿐만 아니라 섬유아 전구세포에서 인슐린에 의한 포도당 홉수를 저해 하였다. 마지막으로 인슐린 수용채, Akt, SHIP2, p85등이 lipid raft/caveolae에 존재함을 확인하였고 인슐린에 의해 이런 단백질 들이 lipid raft/caveolae로 이동함을 관찰하였다. 이런 결과를 토대로 lipid raft는 포도당 흡수 를 위한 인슐린의 기능적 작용을 하는데 매우 중요한 환경을 제공함을 주장한다. 